\title{
Association between sex differences on foot health related to the quality of life in a sample of sedentary people
}

\author{
(iD) Daniel López-López ${ }^{1}$ \\ Jose María Cancela-Carral ${ }^{2}$ \\ (iD) Romeu Araujo ${ }^{2}$ \\ (iD) Marta Elena Losa-Iglesias ${ }^{3}$ \\ Ricardo Becerro-de-Bengoa-Vallejo 4 \\ (iD) David Rodríguez-Sanz ${ }^{4,5}$ \\ (iD) Cesar Calvo-Lobo ${ }^{6}$
}

1. Research, Health and Podiatry Unit. Department of Health Sciences. Faculty of Nursing and Podiatry. Universidade da Coruña, Ferrol, Spain 2. Faculty of Sciences of the Education and of Sport. Universidade de Vigo, Vigo, Spain 3. Faculty of Health Sciences. University Rey Juan Carlos, Alcorcón, Spain 4. Facultad de Enfermería, Fisioterapia y Podología. Universidad Complutense de Madrid, Madrid, Spain 5. Faculty of sport sciences, Universidad Europea de Madrid, Villaviciosa de Odón, Madrid, Spain 6. Nursing and Physical Therapy Department, Faculty of Health Sciences, Universidad de León, Ponferrada, León, Spain

\section{SUMMARY}

Sedentary (sitting) time may produce many anatomical and physiological consequences which are supposedly associated with a decreased quality of life (QoL) related to foot health. Accordingly, this study aimed to analyze the QoL impact on the overall health and the foot health among male and female sedentary people. A total of 312 participants with an age mean of $39.81 \pm 15.40$ years completed all phases of the study. In addition, self-reported data were registered. The participants' sedentary lifestyle was determined using the European Prospective Investigation into Cancer and Nutrition (EPIC) physical activity questionnaire.

Furthermore, the scores obtained from the Portuguese version of the Foot Health Status Questionnaire were registered. Sedentary people in the equivalent metabolic energy had $301.09 \pm 72.22$ ( $\mathrm{min} /$ week). In the first section, values were higher for foot pain and foot function and lower for general foot health and footwear. In the second section, values were higher for general health and vigor and lower for physical activity and social capacity. The differences between the sex groups of the study were statistically significant for footwear $(P=0.008)$, physical activity $(P=0.002)$, social capacity $(P=0.001)$ and vigor $(P=0.001)$ showing a worst QoL related to foot health in favor of male subjects in comparison with females. The rest of the domains did not show any statistically significant difference $(P \geq .01)$. The sedentary population evidenced a negative impact on the QoL related to foot health. This problem may be associated with this lifestyle, especially for males.

KEYWORDS: Foot. Foot Deformities. Foot Injuries. Quality of life. Sedentary lifestyle. 


\section{INTRODUCTION}

Sedentary (sitting) time may be characterized by a lifestyle with reduced walking or activity, which consequently leads to a sitting, reclining or lying posture and decreased energy expenditure $(\leq 1.5$ metabolic equivalent of task) ${ }^{1}$. This condition can have many anatomical and physiological consequences related to impaired health outcomes, leading to the development of anxiety ${ }^{2}$, certain types of cancer ${ }^{3,4}$ cardiovas- $^{-}$ cular diseases ${ }^{4,5}$ cholesterol $^{6}$, depression ${ }^{7}$, diabetes ${ }^{8}$, high blood pressure ${ }^{9}$, metabolic syndrome ${ }^{10}$, musculoskeletal pain ${ }^{11}$, overweight ${ }^{12}$, obesity ${ }^{13}$, osteoporo$\operatorname{sis}^{14}$, and other mortality causes ${ }^{15}$.

Furthermore, the prevalence and severity of sedentary lifestyles in females and males worldwide are high, estimated between $60-85 \%$, with considerable harmful impacts that involve significant public health burdens and an enormous cost for individuals, society, and health care systems ${ }^{16,17}$. However, no prior research has been conducted on the negative health effects on the quality of life (QoL) related to foot health.

Also, there is a high prevalence rate of foot pathologies comprised between $71 \%$ and $93 \%{ }^{18}$ (i.e., cavus foot, flat foot, hallux rigidus, hallux valgus, hyperkeratosis, lesser toe deformities, metatarsalgia, Morton's neuroma, nails disorders, plantar fasciitis and tailor's bunions) ${ }^{18-2}$, which could be associated to a sedentary lifestyle and a potential factor in predicting loss of overall health.

Based on the foregoing and on the need for assessment, evaluation, and examination of the foot health of sedentary people may be very important. Indeed, disorders and alterations of the foot, painful or postural conditions, gait disturbance, the risk of falls and other basic diseases may be considered key factors when planning assistance and preventive health activities to improve QoL, wellbeing, and autonomy for the sedentary population.

Consequently, the goal of this research was to analyze the impact of the QoL related to foot health among male and female sedentary people. We hypothesized that sedentary people might present a negative impact on the QoL related to foot health.

\section{MATERIALS AND METHODS}

\section{Design and Sample}

This research consisted of a cross-sectional observational study carried out in a private podiatric medical and surgical center that provides treatment for foot problems in the city of Porto (Portugal) during the period between October 2016 and October 2017. Participants were selected using a non-randomized consecutive sampling method, and their mean age was $39.81 \pm 15.40$ years. A sample of 312 volunteers was recruited. The exclusion criteria included injury and a history of foot surgery, psychiatric or neurological disorders, diabetes, rheumatoid arthritis, chronic joint pathology, immunocompromised or lack of partial independence in daily activities, refusal to sign a consent form, the inability to follow the instructions necessary to carry out the present study, as well as patients of other nationalities (non-Portuguese) who did not master Portuguese.

\section{Procedure}

Initially, participants were enrolled and interviewed about overall health, sociodemographic characteristics (age and sex) and presence of relevant factors such as arthritis, diabetes, obesity, vascular disease, osteoarticular disorders or participation in sports.

A single trainer researcher conducted a standardized clinical exam. Then, we measured the subject's demographic data, such as height and weight as well as determined the body mass index (BMI), from the height $(\mathrm{m})$, and weight $\left(\mathrm{kg}^{2}\right)$, applying Quetelet's equation (BMI=weight / height $\left.{ }^{2}\right) .{ }^{21}$

Next, the voluntary completed the Portuguese version of the European Prospective Investigation into Cancer and Nutrition (EPIC) Physical Activity Questionnaire $^{22}$. This tool presented a higher construct of the degree, content and validity (Spearman correlation coefficient, $r \mathrm{~s})$ for male $(r \mathrm{~s}=0.47-0.89=$ and female ( $r \mathrm{~s}=0.49-0.81)$. Also, this tool showed a high retest reliability $(r \mathrm{~s}=0.32-0.81$ in male and $r \mathrm{~s}$ $=0.28$-072 in female $)^{23}$. This self-administered instrument determines the duration of physical activity intensities average (day, week and month) in the three different tasks (professional, domestic and free time) and for five types of activities. The first task assesses rest (sleeping or sitting/lying awake). The second task assesses transport to or from work (walking, motorized vehicle, or other). The third task assesses professional activity (very light, light, moderate and heavy). The fourth task assesses household activities (very light, light and moderate). The final task assesses very light activities (watching TV, playing cards, reading) and exercise (light, moderate and heavy).

Also, each participant was measured using the energy cost of expenditure in the daily activities ap- 
plying standard scores of the metabolic energy equivalent multiplied by the time spent in every task ( $\mathrm{min} /$ day) for seven days (min/week) ${ }^{24,25}$.

Subsequently, participants completed the Portuguese version of the Foot Health and Quality of Life (PFHQL) tool that contains two sections ${ }^{26}$. The first section presents thirteen points related to foot pain (four questions), foot function (four questions), footwear (three questions) and general foot health (two questions), differing from other tools that only measure recorded foot pain, function of the foot and disability ${ }^{27,28}$.

Also, PFHQL presented appropriate psychometric properties, a higher construct of the degree, content, and validity (Cronbach $\alpha=0.89-0.95$ ). In addition, a high retest reliability (intraclass correlation coefficient, ICC $=0.74-0.92$ ) was shown ${ }^{29,30}$. The second section of the tool was adapted from the Medical Outcomes Study 36-Item Short-Form Health ${ }^{29}$, and presented items related to overall health (general health, physical activity, social capacity, and vigor), which demonstrated to be a valid measurement questionnaire $^{31}$. The FHSQ software (Version 1.03) showed points from zero (poor health status) to one hundred (better health status).

\section{Sample size calculation}

The sample size was calculated using the Clinical Epidemiology and Biostatistics Research Group software, Universidade da Coruña (http://www.fisterra.com/mbe/investiga/9muestras/9muestras2. asp $)^{32}$. The calculation was based on the population living in Portugal with a total of 6.979.785 adults on October 05, 2017 (https://www.pordata.pt/DB/Municipios/Ambiente $+\mathrm{de}+$ Consulta/Tabela). Considering a 2 -tailed test, an $\alpha$ level of 0.05 , a desired power analysis of $95 \%$ with a $\beta$ level of $20 \%$, a precision of $50 \%$ $(\mathrm{P}=0.5)$ and assuming a loss of participants of $15 \%$, at least 203 participants needed to be studied. Finally, a sample of 312 participants was included in the study.

\section{Ethical considerations}

This study was approved by the local Bioethics Committee of the Hospital-Escola da Fundação Fernando Pessoa in Porto, Portugal (registry number: 30/2017). All voluntary participants gave written informed consent before beginning the investigation protocol. Additionally, the research followed international principles for medical research in human experimentation set forth by the World Medical Association in the Declaration of Helsinki.

\section{Statistical analysis}

The descriptive analysis related to the variables, which appear in this research, was carried out. The qualitative variable (sex) was described as an absolute value. The quantitative variables were described as mean \pm standard deviation (SD), median \pm interquartile range (IR) as well as maximum and minimum values (range) for the male, female and total sedentary sample.

A Kolmogorov-Smirnov test was used to examine the normality of the distribution for all variables, and data were considered normally distributed if $P>0.01$. The Kruskal Wallis test for independent samples was performed to analyze sociodemographic and PFHSQ differences between men and women in the sedentary sample. In all the analyses, $P<.01$ (with a $99 \%$ confidence interval) was considered statistically significant.

The IBM SPSS Statistics 19.0 package for windows was to analyze the results. FHSQ (Version 1.03) was used to obtain the QoL scores related to foot health.

\section{RESULTS}

The results for Kolmogorov Smirnov showed a normal distribution $(\mathrm{P}<0.05)$ for sociodemographic data and PFHSQ scores. Therefore, the non-parametric Kruskal Wallis test was performed.

A total sample of 312 subjects, between 18 and 87 years old with a mean \pm SD of $39.81 \pm 15.40$ years, concluded the investigation pathway. Most participants were of average weight (BMI, $24.75 \pm 3.942 \mathrm{~kg} /$ $\mathrm{m}^{2}$ ) and their metabolic equivalent of tasks showed a sedentary activity (MET, $301.09 \pm 72.22 \mathrm{~min} /$ week). Descriptive socio-demographic characteristics of the people, stratified by sex, are presented in Table 1 .

The findings of the comparison between QoL related to the foot values of sex groups are shown in Table 2. The first specific section for the feet analyzed four domains: 1) pain, 2) function, 3) overall foot health and 4) footwear. The values were higher for foot pain and foot function and lower for general foot health and footwear. The second general section assessed four health domains: 1) overall health, 2) physical function, 3) social capacity, and 4) vitality. The values were higher for general health and vigor and lower for physical activity and social capacity.

The differences between the groups of the study were statistically significant for footwear $(P=$ 0.008), physical activity $(P=0.002)$, social capacity $(P=0.001)$, and vigor $(P=0.001)$ showing a worst $Q o L$ 
TABLE 1: SOCIO-DEMOGRAPHIC AND CLINICAL CHARACTERISTICS OF THE SAMPLE POPULATION

\begin{tabular}{|c|c|c|c|c|}
\hline & $\begin{array}{l}\text { Total Group } \\
\text { Mean } \pm \text { SD } \\
\text { Range } \\
\text { Median } \pm \text { IR } \\
\mathrm{N}=312\end{array}$ & $\begin{array}{l}\text { Male } \\
\text { Mean } \pm S D \\
\text { Range } \\
\text { Median } \pm I R \\
\mathrm{~N}=219\end{array}$ & $\begin{array}{l}\text { Female } \\
\text { Mean } \pm S D \\
\text { Range } \\
\text { Median } \pm I R \\
\mathrm{~N}=93\end{array}$ & $\begin{array}{l}\text { P-Value } \\
\text { Male vs. } \\
\text { Female }^{*}\end{array}$ \\
\hline Age, years & $\begin{array}{l}39.81 \pm 15.40 \\
(18-87) \\
39 \pm 24.25\end{array}$ & $\begin{array}{l}38.15 \pm 14.72 \\
(18-87) \\
37 \pm 23\end{array}$ & $\begin{array}{l}43.72 \pm 16.31 \\
(18-86) \\
41 \pm 24\end{array}$ & 0.005 \\
\hline Weight (kg) & $\begin{array}{l}68.57 \pm 13.11 \\
(40-115) \\
67.00 \pm 19.00\end{array}$ & $\begin{array}{l}63.88 \pm 10.83 \\
(42-98) \\
62 \pm 14\end{array}$ & $\begin{array}{l}79.62 \pm 11.31 \\
(56-115) \\
80 \pm 12.50\end{array}$ & 0.001 \\
\hline Height (m) & $\begin{array}{l}1.66 \pm 0.85 \\
(1.45-1.92) \\
1.65 \pm 0.11\end{array}$ & $\begin{array}{l}1.62 \pm 0.06 \\
(1.45-1.80) \\
1.63 \pm 0.10\end{array}$ & $\begin{array}{l}1.74 \pm 0.07 \\
(1.50-1.92) \\
1.75 \pm 0.10\end{array}$ & 0.001 \\
\hline $\mathrm{BMI}(\mathrm{kg} / \mathrm{m} 2)$ & $\begin{array}{l}24.75 \pm 3.942 \\
(16.78-39.82) \\
24.21 \pm 4.92\end{array}$ & $\begin{array}{l}24.15 \pm 4.17 \\
(16.78-39.82) \\
23.42 \pm 4.97\end{array}$ & $\begin{array}{l}26.17 \pm 2.877 \\
(20.61-36.43) \\
25.82 \pm 3.59\end{array}$ & 0.001 \\
\hline METS (min/day) & $\begin{array}{l}43.82 \pm 10.60 \\
(24.00-80.24) \\
40.14 \pm 15.80\end{array}$ & $\begin{array}{l}43.20 \pm 9.04 \\
(27.99-80.24) \\
40.42 \pm 10.50\end{array}$ & $\begin{array}{l}43.20 \pm 9.04 \\
(24.00-69.83) \\
40.42 \pm 10.50\end{array}$ & 0.583 \\
\hline METS (min/week) & $\begin{array}{l}306.76 \pm 74.21 \\
(168.00-561.73) \\
281.00 \pm 110.66\end{array}$ & $\begin{array}{l}302.44 \pm 63.34 \\
(168.00-488.83) \\
282.98 \pm 73.55\end{array}$ & $\begin{array}{l}302.44 \pm 63.34 \\
(168.00-488.83) \\
282.98 \pm 73.55\end{array}$ & 0.582 \\
\hline
\end{tabular}

Abbreviations: $B M I$, body mass index; METS, metabolic energy equivalent; IR, interquartile range; SD, standard deviation. In all the analyses, $\mathrm{P}<.01$ (with a $99 \%$ confidence interval) was considered statistically significant. ${ }^{*}$ Kruskal Wallis test for independent samples was performed.

TABLE 2: COMPARISONS OF FHSQ SCORES TOTAL GROUP AND SEX GROUP

\begin{tabular}{|c|c|c|c|c|}
\hline & $\begin{array}{l}\text { Total Group } \\
\text { Mean } \pm \text { SD } \\
\text { Range } \\
\text { Median } \pm I R \\
\mathrm{~N}=312\end{array}$ & $\begin{array}{l}\text { Male } \\
\text { Mean } \pm S D \\
\text { Range } \\
\text { Median } \pm I R \\
\mathrm{~N}=219\end{array}$ & $\begin{array}{l}\text { Female } \\
\text { Mean } \pm \text { SD } \\
\text { Range } \\
\text { Median } \pm I R \\
\mathrm{~N}=93\end{array}$ & $\begin{array}{l}\text { P-Value } \\
\text { Male vs. } \\
\text { Female* }\end{array}$ \\
\hline Foot Pain & $\begin{array}{l}78.84 \pm 22.80 \\
(0-100) \\
84.37 \pm 18.12\end{array}$ & $\begin{array}{l}77.31 \pm 22.82 \\
(0-100) \\
84.37 \pm 18.75)\end{array}$ & $\begin{array}{l}82.46 \pm 22.47 \\
(0-100) \\
90 \pm 21.87\end{array}$ & 0.013 \\
\hline Foot Function & $\begin{array}{l}85.92 \pm 20.55 \\
(0-100) \\
93.75 \pm 18.75\end{array}$ & $\begin{array}{l}84.73 \pm 21.28 \\
(0-100) \\
93.75 \pm 18.75\end{array}$ & $\begin{array}{l}88.71 \pm 18.53 \\
(6.25-100) \\
100 \pm 18.75\end{array}$ & 0.104 \\
\hline Footwear & $\begin{array}{l}57.16 \pm 28.67 \\
(0-100) \\
58.33 \pm 41.66)\end{array}$ & $\begin{array}{l}54.30 \pm 28.74 \\
(0-100) \\
58.33 \pm 45.83\end{array}$ & $\begin{array}{l}63.89 \pm 27.51 \\
(0-100) \\
66.66 \pm 33.33\end{array}$ & 0.008 \\
\hline General Foot Health & $\begin{array}{l}63.68 \pm 23.89 \\
(12.50-100) \\
60.00 \pm 42.50\end{array}$ & $\begin{array}{l}62.09 \pm 23.92 \\
(12.50-100) \\
60 \pm 42.5\end{array}$ & $\begin{array}{l}67.42 \pm 23.51 \\
(12.50-100) \\
72.5 \pm 42.5\end{array}$ & 0.057 \\
\hline General Health & $\begin{array}{l}68.46 \pm 22.98 \\
(0-100) \\
70.00 \pm 40.00\end{array}$ & $\begin{array}{l}67.26 \pm 23.12 \\
(0-100) \\
70 \pm 30\end{array}$ & $\begin{array}{l}71.29 \pm 22.52 \\
(10-100) \\
80 \pm 30\end{array}$ & 0.147 \\
\hline Physical Activity & $\begin{array}{l}83.51 \pm 20.87 \\
(0-100) \\
91.66 \pm 22.22\end{array}$ & $\begin{array}{l}81.61 \pm 21.15 \\
(11.11-100) \\
88.88 \pm 27.77\end{array}$ & $\begin{array}{l}87.99 \pm 19.58 \\
(0-100) \\
94.44 \pm 11.11\end{array}$ & 0.002 \\
\hline Social Capacity & $\begin{array}{l}78.33 \pm 21.13 \\
(12.50-100) \\
81.25 \pm 37.50\end{array}$ & $\begin{array}{l}75.34 \pm 21.58 \\
(12.50-100) \\
75 \pm 37.50\end{array}$ & $\begin{array}{l}85.35 \pm 18.30 \dagger \\
(12.50-100) \\
87.5 \pm 25\end{array}$ & 0.001 \\
\hline Vigor & $\begin{array}{l}51.66 \pm 19.34 \\
(0-100) \\
50.00 \pm 31.25\end{array}$ & $\begin{array}{l}49.32 \pm 18.83 \\
(0-100) \\
50 \pm 25\end{array}$ & $\begin{array}{l}57.19 \pm 19.50 \\
(12.50-93.75) \\
56.25 \pm 31.25\end{array}$ & 0.001 \\
\hline
\end{tabular}

Abbreviations: FHSQ, Foot Health Status Questionnaire; IR, interquartile range; SD, standard deviation. In all the analyses, $P<.01$ (with a 99\% confidence interval) was considered statistically significant. "Kruskal Wallis test for independent samples was performed. 
related to foot health in male subjects. The rest of the domains did not show any statistically significant difference $(P \geq .01)$.

\section{DISCUSSION}

This study aimed to analyze the QoL impact on the overall and foot health among male and female sedentary people. Foot health may be very important for the overall health, independence, and QoL in the sedentary population.

Regarding a prior case-control study, a sample of 140 active and sedentary participants with mean age of 40 years in Iran were randomly selected and showed that active people presented better QoL than sedentary people ${ }^{33}$. Nevertheless, the QoL associated with foot health was not analyzed in this context in any investigation.

This is the first study to reveal that sedentary individuals present poor QoL values on the dimensions related to the foot. The outcomes of this research highlighted the need for medical and podiatric care in sedentary people. Sedentary people should be advised about the changes that a sedentary lifestyle will bring to their feet. Therefore, podiatric care would help to improve the lifestyle and overall health in this population.

These findings are consistent with a randomized controlled clinical intervention conducted by Campbell et al. ${ }^{34}$, which indicated that leg, ankle, and foot are habitually sites of the most pathologies in sedentary individuals.

Furthermore, this investigation revealed a significant increase in PFHSQ scores for foot pain, foot function, general health, vigor and lower scores for general foot health, footwear physical activity, and social capacity in the levels of QoL related with foot health in sedentary people. This is consistent with research that has demonstrated that lifestyle affects the risk of illnesses, symptoms, poorer response to treatment, and a significant increase in the use of medical services ${ }^{11,35,36}$

However, this study presented several limitations that should be acknowledged. Firstly, a new classification related to different lifestyles may help identify if there are other mechanisms involved. Secondly, sub-categories of metabolic energy equivalent would be beneficial to improve the strength of the study. Finally, expanding data collection to other countries would be beneficial to strengthen this study. This highlights the need for further studies that should focus on foot health, lifestyle and QoL of the population.

\section{CONCLUSIONS}

The sedentary population evidenced a negative impact on the QoL related to foot health. This problem may be associated with this lifestyle, especially in the males.

\section{DECLARATIONS}

\section{Ethics approval and consent to participate}

This study was approved by the local Bioethics Committee of the Hospital-Escola da Fundação Fernando Pessoa in Porto, Portugal (registry number: 30/2017). All voluntary participants gave written informed consent before beginning the investigation protocol.

\section{Consent for publication}

The authors declare that they consent for publication.

\section{Availability of data and material}

The data set supporting the conclusions of this article is available in the daniellopez@udc.es in the Research, Health and Podiatry Unit. Department of Health Sciences. Faculty of Nursing and Podiatry. Universidade da Coruña, Spain.

\section{Competing interests}

The authors report no conflicts of interest in this work.

\section{Funding}

The authors did not receive any funding for the design, methods, subject recruitment, data collections, analysis and preparation of the paper or have any personal relationships with other people or organizations that could inappropriately influence (bias) their work.

\section{Authors' contributions}

All authors: concept, design, analyses, interpretation of data, drafting of the manuscript and revising it critically for important intellectual content.

\section{Authors' information (optional)}

None 


\section{RESUMO}

O tempo sedentário (sentado) pode produzir muitas consequências anatômicas e fisiológicas que supostamente estão associadas a uma redução de qualidade de vida (QoL) relacionada à saúde do pé. Por conseguinte, o objetivo deste estudo foi analisar o impacto da QV sobre a saúde geral e a saúde do pé entre pessoas sedentárias masculinas e femininas. Uma amostra de 312 participantes com idade média de 39,81 \pm 15,40 anos completou todas as fases do processo de estudo. Além disso, os dados autorrelatados foram registrados. O comportamento sedentário dos informantes foi determinado usando o questionário de prospecção prospectiva de câncer e nutrição (Epic). Além disso, os resultados obtidos com a versão em português do Questionário de Status de Saúde do Pé (PFHSQ) foram registrados. As pessoas sedentárias no equivalente de energia metabólica apresentaram 301,09 \pm 72,22 (min/semana). Na primeira seção, os valores foram maiores para a dor no pé e função do pé e diminuíram a saúde e o calçado do pé geral. Na segunda seção, os valores foram maiores para saúde geral e vigor e menores para atividade física e capacidade social. As diferenças entre os grupos sexuais do estudo foram estatisticamente significativas para o calçado $(P=0,008)$, atividade física $(P=0,002)$, capacidade social $(P=0,001)$ e vigor $(P=0,001)$, mostrando uma pior $Q V$ relacionada à saúde do pé a favor dos sujeitos do sexo masculino em relação aos participantes sedentários femininos. O restante dos domínios não apresentou diferença estatisticamente significante $(P \geq$ 0,01 ). A população sedentária evidenciou um impacto negativo na QoL relacionada à saúde dos pés. Esse problema pode estar associado a este comportamento, especialmente no sexo masculino.

PALAVRAS-CHAVE: Pé. Deformidades do pé. Traumatismos do pé. Qualidade de vida. Estilo de vida sedentário.

\section{REFERENCES}

1. Sedentary Behaviour Research Network. Letter to the editor: standardized use of the terms "sedentary" and "sedentary behaviours." Appl Physiol Nutr Metab. 2012;37(3):540-2.

2. Teychenne M, Costigan SA, Parker K. The association between sedentary behaviour and risk of anxiety: a systematic review. BMC Public Health. 2015;15:513.

3. Friberg E, Mantzoros CS, Wolk A. Diabetes and risk of endometrial cancer: a population-based prospective cohort study. Cancer Epidemiol Biomarkers Prev. 2007;16(2):276-80

4. Katzmarzyk PT, Church TS, Craig CL, Bouchard C. Sitting time and mortality from all causes, cardiovascular disease, and cancer. Med Sci Sport Exerc. 2009;41(5):998-1005.

5. Thorp AA, Owen N, Neuhaus M, Dunstan DW. Sedentary behaviors and subsequent health outcomes in adults a systematic review of longitudinal studies, 1996-2011. Am J Prev Med. 2011;41(2):207-15.

6. Ip S, Lichtenstein AH, Chung M, Lau J, Balk EM. Systematic review: association of low-density lipoprotein subfractions with cardiovascular outcomes. Ann Intern Med. 2009;150(7):474-84

7. Zhai L, Zhang Y, Zhang D. Sedentary behaviour and the risk of depression: a meta-analysis. Br J Sports Med. 2015;49(11):705-9.

8. Wilmot EG, Edwardson CL, Achana FA, Davies MI, Gorely T, Gray LI, et al. Sedentary time in adults and the association with diabetes, cardiovascular disease and death: systematic review and meta-analysis. Diabetologia. 2012;55(11):2895-905.

9. Agyemang C, Kieft S, Snijder MB, Beune El, van den Born B], Brewster $L M$, et al. Hypertension control in a large multi-ethnic cohort in Amsterdam, The Netherlands: the HELIUS study. Int J Cardiol. 2015;183:180-9.

10. Biswas A, Oh PI, Faulkner GE, Bajaj RR, Silver MA, Mitchell MS, et al. Sedentary time and its association with risk for disease incidence, mortality, and hospitalization in adults. Ann Intern Med. 2015;162(2):123-32.

11. Stefansdottir R, Gudmundsdottir SL. Sedentary behavior and musculoskeletal pain: a five-year longitudinal Icelandic study. Public Health. 2017; 149:71-3.

12. Pulsford RM, Stamatakis E, Britton AR, Brunner EJ, Hillsdon M. Associations of sitting behaviours with all-cause mortality over a 16-year follow-up: the Whitehall II study. Int J Epidemiol. 2015;44(6):1909-16.

13. Shields M, Tremblay MS. Sedentary behaviour and obesity. Health Rep. 2008;19(2):19-30.

14. Vicente-Rodríguez G, Ortega FB, Rey-López JP, España-Romero V, Blay VA, Blay G, et al. Extracurricular physical activity participation modifies the association between high TV watching and low bone mass. Bone. 2009;45(5):925-30.

15. Inoue M, Yamamoto S, Kurahashi N, Iwasaki M, Sasazuki S, Tsugane S. Japan Public Health Center-based Prospective Study Group. Daily total physical activity level and total cancer risk in men and women: results from a large-scale population-based cohort study in Japan. Am J Epidemiol. 2008;168(4):391-403.
16. World Health Organization. Physical inactivity a leading cause of disease and disability, warns WHO. [cited 2018 April 7]. Geneva: WHO. Available from: http://www.who.int/mediacentre/news/releases/release23/en/.

17. Varo JJ, Martínez-González MA, Irala-Estévez J, Kearney J, Gibney M, Martínez JA. Distribution and determinants of sedentary lifestyles in the European Union. Int J Epidemiol. 2003;32(1):138-46.

18. Pita-Fernandez S, González-Martin C, Seoane-Pillado T, Pertega-Diaz S, Perez-Garcia S, López-Calviño B. Podiatric medical abnormalities in a random population sample 40 years or older in Spain. J Am Podiatr Med Assoc. 2014;104(6):574-82.

19. Rodríguez-Sanz D, Tovaruela-Carrión N, López-López D, Palomo-López P, Romero-Morales C, Navarro-Flores, et al. Foot disorders in the elderly: a mini-review. Dis Mon. 2018;64(3):64-91.

20. Pita-Fernandez S, Gonzalez-Martin C, Alonso-Tajes F, Seoane-Pillado T, Pertega-Diaz S, Perez-Garcia S, et al. Flat foot in a random population and its impact on quality of life and functionality. J Clin Diagn Res. 2017;11(4):LC22-7.

21. Centers of Disease Control. Body mass index: considerations for practitioners. Cdc. 2011:4. [Cited 2016 Dec 16]. Available from: http://scholar. google.com/scholar?hl=en\&btnG=Search\&q=intitle:Body+Mass+Index$+:+$ Considerations+for+Practitioners\#3\%5Cnhttp://scholar.google.com/ scholar?hl=en\&btnG=Search\&q=intitle:Body+mass+index:+Considerations+for+practitioners\%233.

22. Camões M, Severo M, Santos AC, Barros H, Lopes C. Testing an adaptation of the EPIC physical activity questionnaire in Portuguese adults: a validation study that assesses the seasonal bias of self-report. Ann Hum Biol. 2010;37(2):185-97.

23. Pols MA, Peeters PH, Ocké MC, Slimani N, Bueno-de-Mesquita HB, Collette $\mathrm{HI}$. Estimation of reproducibility and relative validity of the questions included in the EPIC Physical Activity Questionnaire. Int J Epidemiol. 1997;26(Suppl 1):S181-9.

24. World Health Organization. WHO Guidelines Approved by the Guidelines Review Committee. Global Recommendations on physical activity for health. Geneva: World Health Organization; 2010.

25. Ainsworth BE, Haskell WL, Leon AS, Jacobs DR Jr, Montoye HI, Sallis JF, et al. Compendium of physical activities: classification of energy costs of human physical activities. Med Sci Sports Exerc. 1993;25(1):71-80.

26. Cuesta-Vargas A, Bennett $P$, Jimenez-Cebrian AM, Labajos-Manzanares MT. The psychometric properties of the Spanish version of the Foot Health Status Questionnaire. Qual Life Res. 2013;22(7):1739-43.

27. Gijon-Nogueron G, Ndosi M, Luque-Suarez A, Alcacer-Pitarch B, Munuera PV, Garrow A, et al. Cross-cultural adaptation and validation of the Manchester Foot Pain and Disability Index into Spanish. Qual Life Res. 2014;23(2):571-9.

28. Paez-Moguer J, Budiman-Mak E, Cuesta-Vargas Al. Cross-cultural adaptation and validation of the Foot Function Index to Spanish. Foot Ankle Surg. 2014;20(1):34-9. 
29. Bennett P|, Patterson C, Wearing S, Baglioni T. Development and validation of a questionnaire designed to measure foot-health status. J Am Podiatr Med Assoc. 1998;88(9):419-28.

30. Ferreira AF, Laurindo IM, Rodrigues PT, Ferraz MB, Kowalski SC, Tanaka C. Brazilian version of the foot health status questionnaire (FHSQ-BR): cross-cultural adaptation and evaluation of measurement properties. Clinics (Sao Paulo). 2008;63(5):595-600.

31. Landorf KB, Radford JA. Minimal important difference: values for the Foot Health Status Questionnaire, Foot Function Index and Visual Analogue Scale. Foot. 2008;18(1):15-9.

32. Pita Fernández S. Determinación del tamaño muestral. Cad Aten Primaria. 1996;3:138-52

33. Semnani ASH, Ramezani ZN, Samaee L. A comparison of the health relat- ed quality of life of the active and sedentary faculty members of IAU. Euro J Exp Bio. 2012;2 (5):1843-6.

34. Campbell K, Foster-Schubert K, Xiao L, Alfano C, Bertram LC, Duggan C, et al. Injuries in sedentary individuals enrolled in a 12-month, randomized, controlled, exercise trial. J Phys Act Health. 2012;9(2):198-207.

35. Pinto D, Song J, Lee J, Chang RW, Semanik PA, Ehrlich-Jones LS, et al. Association between sedentary time and quality of life from the osteoarthritis initiative: who might benefit most from treatment? Arch Phys Med Rehabil. 2017;98(12):2485-90.

36. Dogra S, Ashe MC, Biddle SJH, Brown WJ, Buman MP, Chastin S, et al. Sedentary time in older men and women: an international consensus statement and research priorities. Br J Sports Med. 2017:51(21):152632. 